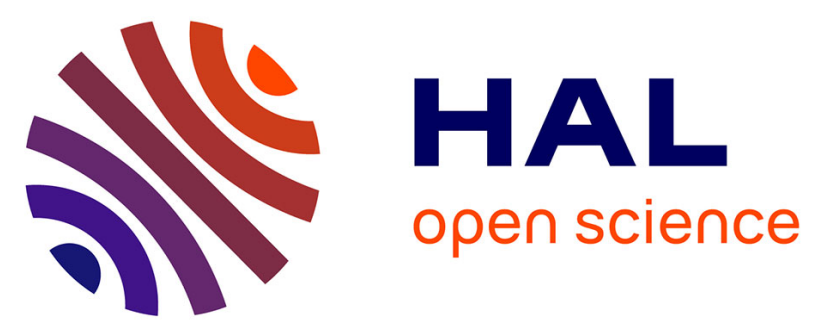

\title{
The effects of annoyance due to aircraft noise on psychological distress: Results of the DEBATS study in France
}

Clémence Baudin, Marie Lefevre, Bernard Laumon, Anne-Sophie Evrard

\section{- To cite this version:}

Clémence Baudin, Marie Lefevre, Bernard Laumon, Anne-Sophie Evrard. The effects of annoyance due to aircraft noise on psychological distress: Results of the DEBATS study in France. EUROEPI 2018, European Congress of Epidemiology, Jul 2018, Lyon, France. EUROEPI 2018, European Congress of Epidemiology, 1 p, 2018. hal-01839936v2

\section{HAL Id: hal-01839936 \\ https://hal.science/hal-01839936v2}

Submitted on 15 Mar 2021

HAL is a multi-disciplinary open access archive for the deposit and dissemination of scientific research documents, whether they are published or not. The documents may come from teaching and research institutions in France or abroad, or from public or private research centers.
L'archive ouverte pluridisciplinaire HAL, est destinée au dépôt et à la diffusion de documents scientifiques de niveau recherche, publiés ou non, émanant des établissements d'enseignement et de recherche français ou étrangers, des laboratoires publics ou privés. 


\title{
The effects of annoyance due to aircraft noise on psychological distress: Results of the DEBATS study in France
}

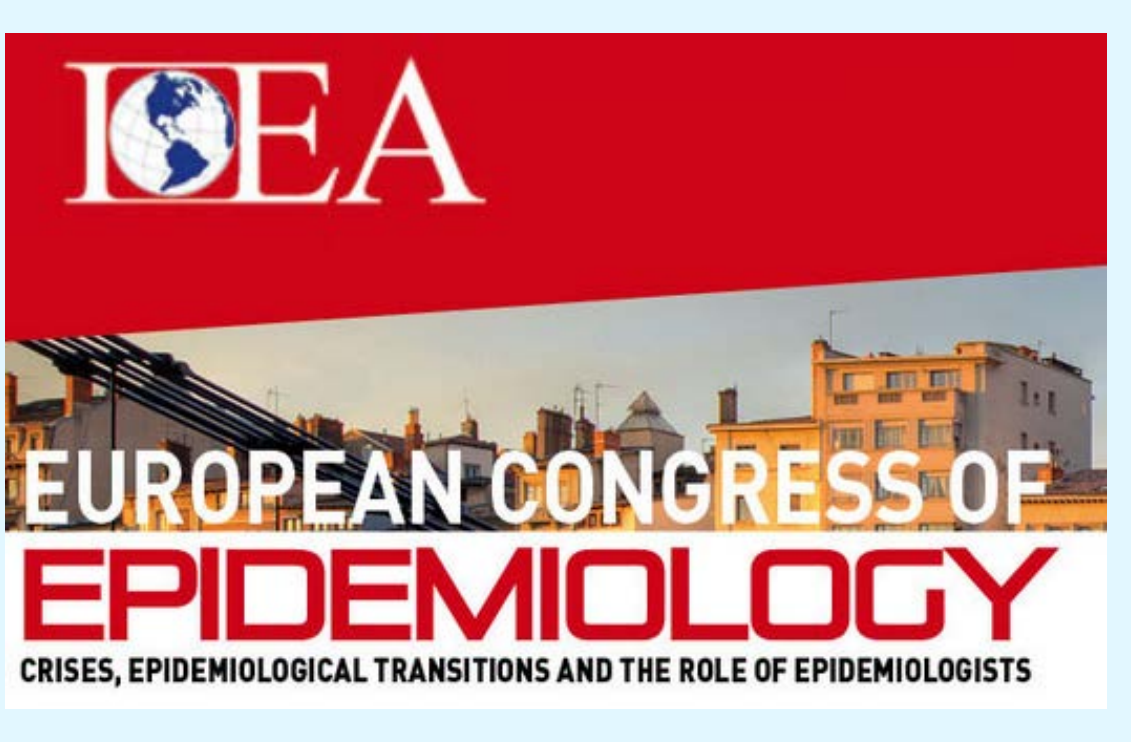

\author{
Clémence BAUDIN ${ }^{1}$, Marie LEFÈVRE ${ }^{1}$, Bernard LAUMON², Anne-Sophie EVRARD ${ }^{1}$ \\ ${ }^{1}$ Univ Lyon, Université Claude Bernard Lyon1, IFSTTAR, UMRESTTE, UMR T_9405, Bron, France \\ ${ }^{2}$ IFSTTAR, Transport, Health and Safety Department, Bron, France
}

Contact: clemence.baudin@ifsttar.fr

\section{Background}

Many studies have evidenced adverse effects of exposure to aircraft noise on health: altered cognitive performance, annoyance, sleep disturbance, hypertension and cardiovascular diseases [1]-[5].

Some studies support the hypothesis that psychological aspects such as noise annoyance play an important role in the association between environmental noise and adverse effects on health [6].

The effects of annoyance due to aircraft noise on psychological distress have rarely been evaluated. No study has been carried out in France [7].

\section{Methods}

\section{Study Population}

1,244 participants living in the vicinity of Paris-Charles-de-Gaulle, Lyon-Saint-Exupery and Toulouse-Blagnac airports in 2013.

\section{Objectives}

One of the objectives of the DEBATS study (Discussion on the health effects of aircraft noise) was to investigate the association between annoyance due to aircraft noise and psychological distress among people living in the vicinity of airports in France.

\section{Results}

Distribution of aircraft noise exposure in the three airports

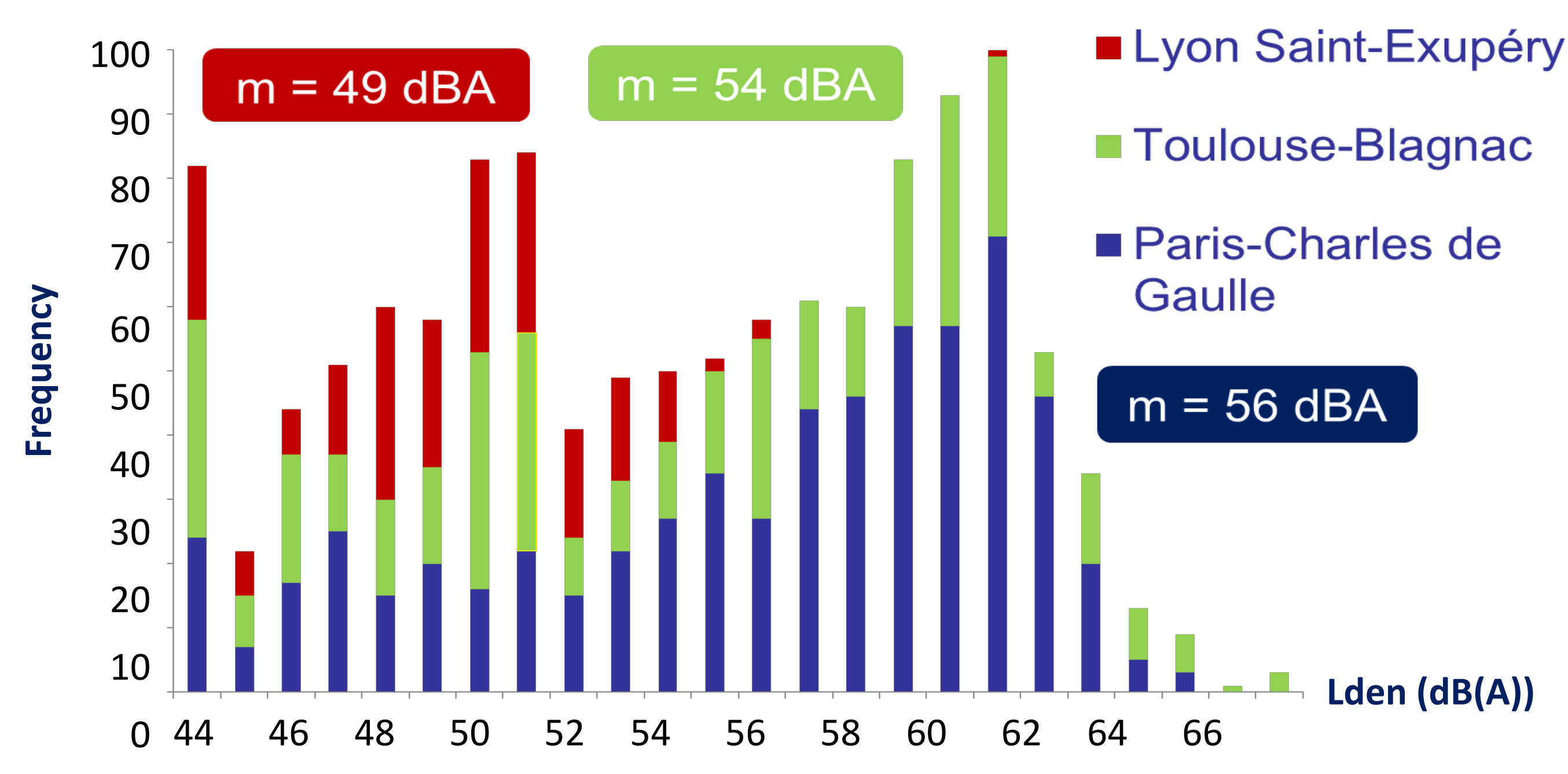

Psychological distress was significantly associated with annoyance due to aircraft noise

Odds ratios (ORs) for the association between aircraft noise annoyance and psychological ill-health (GHQ-12)

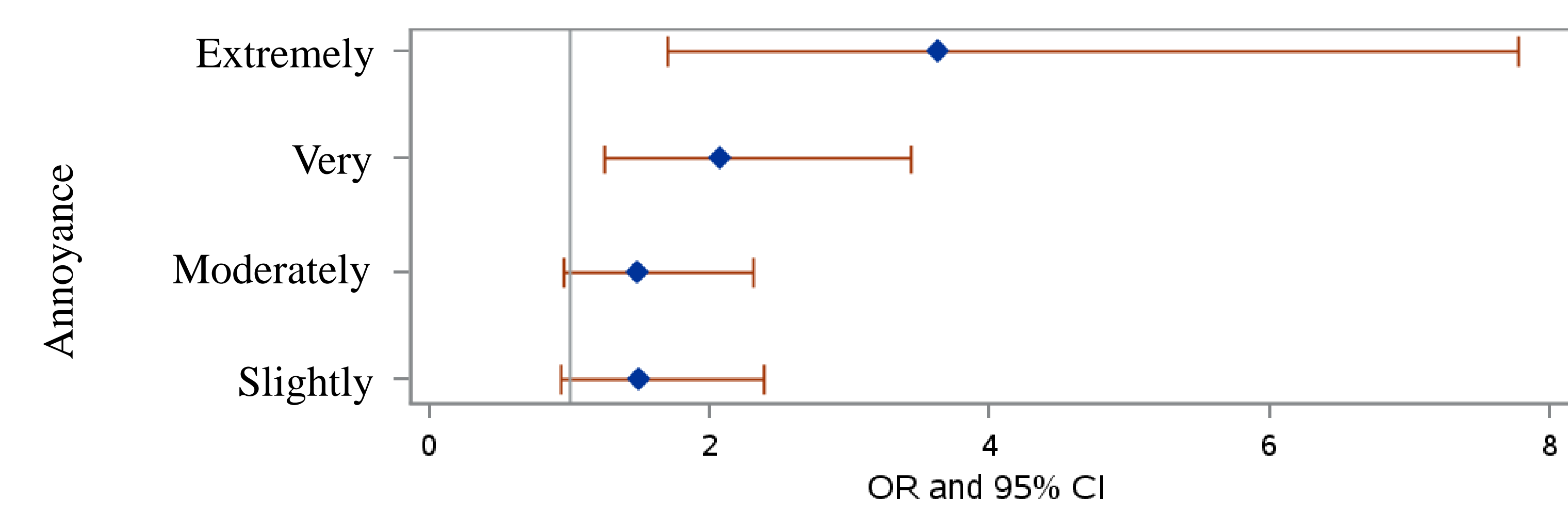

Odds ratios (ORs) for the association between aircraft noise annoyance

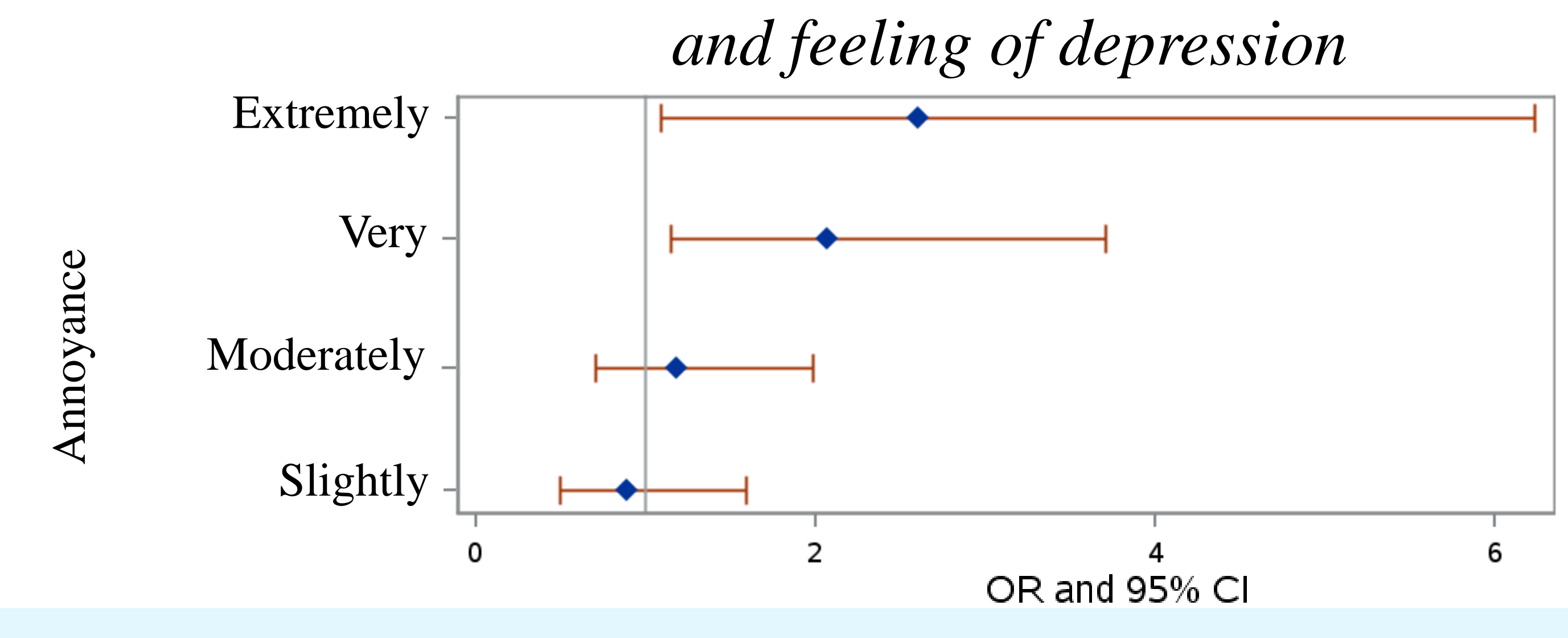

\section{Conclusions}

The present study suggests that annoyance due to aircraft noise is significantly associated with psychological distress, both evaluated with a single question on feeling of depression, and with a validated questionnaire (GHQ-12). It confirms the findings of van Kamp et al. [7].

However, the direction of the association can be questioned: extremely annoyed people might be more at risk to have psychological distress, or people with psychological distress might be more at risk to be annoyed.

Residual confounding or declaration bias cannot be excluded in the present study. Further studies are necessary in order to explain these results.

\section{Acknowledgments}

The authors are grateful to all the participants involved in the study, and their interviewers. 